УДК $821.111-1$

\title{
ДЕКІЛЬКА СЛІВ ПРО “ПОЕЗІЮ ДУШІ”: АНГЛІЙСЬКА ЛІРИКА ЗЛАМУ СТОЛІТь
}

В одному з харківських видавництв 2013 року вийшло друком вагоме дослідження, монографія українського науковця Свгенії Чернокової, присвячена маловивченому аспекту літературознавства - англійській ліриці початку XX ст. І справа не тільки в тому, що ця праця вельми цікава для дослідників літературних процесів, але й у тому, що вона є прикладом сьогоднішнього зацікавлення науковців поезією як специфікою літературного процесу. Можливо, саме цієї думкою і керувалася дослідниця, адже місце лірики в спадщині багатьох англійських поетів та письменників - В. Овена, А. Розенберга, Е. Томаса, Д. Г. Лоренса, Е. Павнда та Т. Еліота - “вивчено недостатньо” [3, с. 9]. Як наслідок маємо наукову працю, яку певною мірою можна назвати відкриттям у царині вітчизняного літературознавства.

Коли читаєш монографію Свгенії Чернокової, розумієш, що перед тобою робота людини, дійсно залюбленої в англійську літературу, а саме в англійську поезію, робота, що писана $з$ натхненням, з умінням глибоко проникати в найтонші сфери митецького уявлення, у творчий задум обраних для дослідження поетів-ліриків.

Відкриває дослідження вступ, у якому скромно зазначені загальна мета та завдання роботи, які полягають у зіставленні певних наукових теорій лірики і з розглядом “характеру лірики як форми літературної творчості у всьому розмаїтті її видів та лірики як того “першоелементу", що має здатність всепроникнення в поезію, прозу, поему чи роман” [3, с. 9-12].

Наступною ланкою монографії $є$ перший розділ, у якому висвітлюється “георгіанський компроміс" у англійській поезії початку XX століття [3, с. 13-41]. Тут розглянуто георгіанську поезію в цілому, виокремлено, як зазначає дослідниця, “домінанти, що об’єднують не тільки учасників антологій, але й тих, хто формально залишився за їхнім бортом та в естетичних параметрах може бути названий його вершинами (Е. Томас, Р. Фрост)" [3, с. 34]; підкреслено популярність георгіанства серед читачів початку століття; наголошено, що “літературна боротьба була для георгіанців не війною, а полемікою, спором, постійним порівнянням. Звідси - уважне відношення до поезії взагалі, а не тільки до творчості однодумців"; переконливо доведено, що “георгіанство та модернізм не існували ізольовано, але близько торкалися навіть в уявленні передових критиків початку століття" [3, с. 40]. Отже, погляд авторки на георгіанство в історії англійської поезії, що представлений у розділі, став своєрідним наближенням, так би мовити місточком до розгляду наступних розділів про героїчне в англійській ліриці Першої світової війни [3, с. 42-125], про лірику Едварда Томаса [3, с. 126-213], про проблеми естетики та поетики в ліриці Д. Г. Лоренса [3, с. 214-281], про “поезію культури”, до якої дослідниця відносить ранню лірику Е. Павнда та Т. С. Еліота [3, с. 282-319].

Що насамперед вражає в роботі Свгенії Чернокової?! По-перше, величезний масив опрацьованого та ретельно дослідженого матеріалу: крізь уважне прочитання, власні спостереження, аналіз та інтерпретацію воєнної поезії Вілфреда Овена, Айзека Розенберга, Зігфрида Сассуна, Руперта Брука та інших митців, читачеві надається картина внутрішнього світу зазначених поетів. Окремо варто відзначити, що дослідниці притаманне природне вміння занурюватися в мову тексту оригіналу, “зчитування” того, що приховано за ним,

(C) Гончаренко E., 2014 
витончене сприйняття поезії. І звідси прекрасні та майстерно виконані авторкою підрядкові переклади, які допомогли їй також “вималювати” такі потрібні для розуміння образу автора біографічні деталі. О. І. Купрін писав: “...для перекладу з іноземної мови недостатньо знати, хоча й на відмінно, цю мову, але й треба ще вміти проникати в глибоке, живе, різноманітне значення кожного слова і в таємну владу поєднання тих або інших слів" [2, с. 12]. Саме цей шлях і обирає авторка роботи.

По-друге, у процесі читання монографії приваблює незвичний підхід у репрезентації досліджуваного матеріалу: власні спостереження дослідниці підкріплюються значною кількістю коментарів, історико-літературними поглядами літературознавців, відсутністю звичних штампованих кліше, що також підкреслює наявність особистого, вишуканого стилю науковця. Це ніби спокійна, виважена розмова Свгенії Чернокової про певний літературний жанр - лірику; розмова, в якій вдало поєднано наукові теорії лірики з життєписом англійських поетів зазначеної доби. Отже, невипадковими в дослідженні є аналіз та інтерпретація лірики воєнних поетів - Едварда Томаса, Айзека Розенберга та інших, ранньої лірики Павнда “Г”ю Селвін Моберлі”, “Портрета дами” Т. С. Еліота, лірики Д. Г. Лоренса, що свідчить про філологічну обізнаність та наукову дорослість авторки. До речі, детальний розгляд останніх є першиною у вітчизняному літературознавстві, і ця першість позначається і в змалюванні біографічних портретів поетів, яке вдало поєднується $з$ жанрологічними спостереженнями науковця.

Не можемо оминути увагою також розділ у книзі Свгенії Чернокової, який присвячено поезії Лоренса. Творчість “шукача” кохання з “туманного Альбіону” [1, с. 236-239] вважається дійсно суперечливою і ставлення літературознавців до Лоренса-митця - письменника та поета - неоднозначне. Ось чому у праці дослідниці приємною знахідкою виглядає лірика Лоренса (своє митецьке життя він починав саме з поезіі), яка представлена як система, як невід'ємна частина лірики зламу століть. Аналіз та інтерпретацію збірок “Дивись! Нам вдалося!", “Птахи, звірі, квіти”, “Останні вірші” здійснено переконливо, підкреслюється “винятковість поезії митця серед “мейн стриму” початку ХХ століття” [3, с. 217].

I на закінчення. $€$ книги, які залишаються поза увагою читача. $Є$ книги, які залишають у читача певний присмак. Іноді це присмак не-бажання повернутися до читання: прочитав та забув, а іноді - це відчуття сприйняття навколишнього світу під певним кутом зору, читаєш і захоплюєшся, немов опиняєшся в полоні, розумієш, що перед тобою високо інтелектуальне читання, бо писати про поезію без натхнення, без любові в душі, без “поезії душі” неможливо. На нашу думку, авторці цілком властива ця “поезія душі”, що надихнула iï та допомогла створити істинно творчу, багатогранну та витончену дослідницьку працю, якій притаманні якості логіки інтерпретування, пильного філологічного аналізу літературознавчих портретів, всебічного розгляду конкретного історико-літературного контексту. Як би добре було, щоб саме такої літератури траплялося якомога більше, бо хороші книги живлять наші душі, розбуджують “поезію душі”.

Елла Гончаренко

1. Гончаренко Е. П. “Шукач” кохання з “туманного Альбіону” / Е. П. Гончаренко // Всесвіт. - 2010. - № 7-8. - С. 236-239. 2. Любимов Н. М. Книга о переводе : сборник / Н. М. Любимов. - М. : Б.С.Г. - ПРЕСС, 2012. - 301 с. 3. Чернокова С. С. Англійська лірика 1900-1920-років і становлення модернізму / С. С. Чернокова. - Харків : Компанія СМIT, 2013. - 363 с. 